\title{
PERAN MADRASAH DALAM PEMBELAJARAN FIQIH TERHADAP TRADISI MERARIQ FAKTOR PENDUKUNG DIPERTAHANKANNYA OLEH MASYARAKAT KEKAIT KECAMATAN GUNUNGSARI LOMBOK BARAT (Studi Kasus Peranan Madrasah di Desa Terpencil)
}

\author{
Oleh: Husnan
}

\begin{abstract}
Abstrak
Pada masyarakat Islam sasak di Lombok terdapat dua bentuk proses pernikahan sebelum terjadinya akad nikah yaitu merariq dan ngelakoq. Merariq merupakan proses perkawinan yang dilakukan dengan cara melarikan atau mencuri gadis (calon pengantin wanita) menuju rumah keluarga calon pengantin pria untuk selanjutnya dinikahkan. Perkawinan dengan cara seperti ini disebut juga dengan memaling (mencuri). Merariq merupakan adat masyarakat yang memiliki landasan hukum di dalam Islam sendiri yaitu `urf. 'urf oleh para ulama' dapat dijadikan sumber pengambilan hukum selama tidak bertentangan dengan sumber utama yaitu al-Qura`an dan al-Hadits serta akal sehat. Merariq dapat dikategorikan sebagai `urf, oleh karena itulah masyarakat sampai hari ini tetap menjalankannya. Akan tetapi 'urf yang berlaku di masyarakat Kekait sering memicu permasalahan antar kedua belah pihak. Nah disinilah peranan madrasah untuk memberikan penerangan dan jalan keluar terhadap permasalahan merariq (menikah) ini.

Penelitian ini merupakan penelitian kualitatif, dimana untuk memperoleh berbagai data digunakan pendekatan fenomenologi diskrif. Adapun teknik-teknik yang digunakan untuk memperoleh data dilapangan yaitu: teknik observasi, wawancara terbimbing dan dokumentasi. Dari penelitian ini ditemukan bahwa relevansi tradisi merariq perlu untuk dipertimbangkan kembali sebagai salah satu adat masyarakat Sasak karena dampak negatif yang timbulkannya. Merariq tidak lagi sebagai simbul heroisme seperti makna dasar filosofisnya, bahkan sebaliknya merariq merupakan simbul ketidak beranian seseorang untuk meminta izin kepada orang tua si perempuan.
\end{abstract}

Kata kunci: Merariq, Ngelakoq, 'Urf

\section{A. PENDAHULUAN}

Pendidikan merupakan suatu proses untuk menjadikan manusia agar mengenal potensi dirinya baik potensi jasmani, intelektual dan spiritual sehingga bisa menjadi warga negara yang baik melalui proses pembelajaran yang dilakukan secara sadar dan terencana. Hal ini sesuai dengan apa yang dinyatakan dalam undang-undang nomor 20 tahun 2003 tentang Sistem Pendidikan Nasional bahwa 
pendidikan adalah usaha sadar dan terencana untuk mewujudkan suasana belajar dan proses pembelajaran agar peserta didik secara aktif mengembangkan potensi dirinya untuk memiliki kekuatan spiritual keagamaan, pengendalian diri, kepribadian, kecerdasan, akhlak mulia, serta keterampilan yang diperlukan dirinya, masyarakat, bangsa dan negara. ${ }^{1}$ Walaupun tertulis jelas dalam undangundang akan tetapi realita pendidikan tidak semulus seperti dalam undang undang. Karena masalah pembelajaran tidak dapat dilepaskan dari sosiokultural masyarakat setempat. Dengan demikian madrasah sebagai gerakan Islam yang memberikan angin segar terhadap fenomena dari realitas sosial dalam kehidupan masyarakat.

Kemampuan Islam dalam mengakulturasi budaya lokal, menyebabkan Islam dapat diterima. Hal tersebut telah terbukti dalam lintasan sejarah Islam mulai dari budaya Arab Persi India, Eropa sampai Melayu. Perbedaan-perbedaan budaya yang dimiliki oleh setiap suku bangsa yang telah dikuasai Islam diakulturasi dalam satu budaya yang terbingkai dengan nilai-nilai Islam. Inilah sebenarnya makna dari "Islam adalah Rahmatan Lilalamin".

Secara historis munculnya suatu hukum dalam Islam tidak terlepas realitas sosial yang terjadi (asbabun nuzul/asbabul wurud). Oleh karena itu relasi antara Islam sebagai agama dengan budaya lokal memiliki hubungan yang sangat erat dalam kajian antropologi umat Islam di pulau Lombok memiliki masjid hampir di setiap dusun. Untuk itulah kemudian ia disebut dengan pulau seribu masjid. Namun pada sisi lain, masyarakat muslim Lombok juga tidak dapat melepaskan diri dari budaya lokal yang berasamaan eksis. Pada situasi inilah kemudian terjadi akulturasi antara budaya atau tradisi lokal menjadi bagian dari pada pola kehidupan beragama mereka. Sehingga terjadi semacam adaptasi budaya yang tercermin dalam pola hidup mereka yang mengekspresikan nuansa keagamaan sebagai bentuk relijiusitasnya, dan adat

\footnotetext{
1 Undang-undang Republik Indonesia Nomor 20 tahun 2003 tentang Sistem Pendidikan Nasional.
} 
budaya sebagai kearifan lokal yang harus dijaga karena warisan nenek moyang. Adat istiadat tersebut tercermin dalam berbagai bidang kehidupan masyarkat Lombok seperti pakaian, bahasa, bentuk rumah perkawinan dan sebagainya. ${ }^{2}$ Fenomena merariq memiliki kekuatan struktural yang diwariskan secara turun temurun dari satu generasi pada generasi berikutnya, yang mana tidak memerlukan alasan rasional karena tindakan itu melembaga dan menebarkan daya ikat kultural yang kuat. Hal ini dipertegas oleh Bartholomew dalam Abdusyakur sebagai berikut:

"Pelarian diri kadang-kadang dianggap sebagai sebuah intisari praktek adat sasak, meskipun sebenarnya hal ini praktik ini dipinjam dari orang-orang Bali. Pelarian diri merupakan praktik yang dihormati di daerah-daerah tertentu yang menekankan pelarangan meminta kepada seseorang secara langsung atas anak perempuannya untuk dinikahi karena hal ini dianggap penghinaan terhadapnya, anak wanitanya dan keluarganya. Seorang laki-laki tua mengatakan kepada saya bahwa permintaan semacam ini nadanya sama dengan meminta seekor ayam". 3

Dengan demikian terjadi dualisme pada pola hidup masyarakat Lombok antara adat istiadat dan agama. Sehingga terjadi tarik ulur antara mempertahankan adat istiadat karena diyakini sebagai aturan hukum yang telah terintegrasi dalam pola perilaku masyarakat, atau agama (sunnah) sebagai pedoman hidup yang telah dicontohkan oleh Rasullulah yang harus diikuti oleh umat Islam, dimana saja dan kapan saja.

Proses pra nikah kedua disebut ngalakoq ${ }^{4}$. Ngelakoq adalah proses perkawinan yang dilakukan dengan cara meminta izin atau melamar si gadis secara resmi terlebih dahulu kepada orang tuanya untuk dijadikan sebagai istri oleh seorang

\footnotetext{
2 Jurnal transformasi oleh Ahmad Junaidi, Adat Istiadat dan Pola Hidup Masyarakat Desa Anyar Kecamatan Bayan Kabupaten Lombok Utara, hal. 209

${ }^{3}$ Ahmad Abd Syakur, Akulturasi Nilai-nilai Islam dalam Budaya Sasak, (Yogyakarta:Adab Press, 2006), hal. 248

${ }^{4}$ Ngalakoq disebut juga dengan nunas, ngendeng yang berarti meminta.
} 
pemuda (calon suami). Tradisi seperti ini sama dengan sistem khitbah dalam Islam, bahkan perkawinan dengan sistem ngelakoq ini dipengaruhi oleh ajaran Islam yang dibawa oleh para penyebar Islam yang berasal dari Jawa sebelum Lombok di kuasai oleh kerajaan Bali. Cara merariq adalah cara yang kurang etis dan berwibawa. Namun, bila melihat fenomena sistem perkawinan pra akad pada masyarakat maka merariq lebih banyak dilakukan dari pada ngelakoq. ${ }^{5}$

Penelitian ini akan dilakukan di desa Kekait kecamatan Gunungsari, yang mana Gunungsari oleh Abdusyakur dikategorikan sebagai kecamatan dengan warganya telah memiliki pengetahuan agama relatif lebih maju ${ }^{6}$. Desa Kekait dijadikan tempat penelitian karena warga desa Kekait sebagian besarnya adalah pelaku kawin dengan sistem merariq. Selain itu, yang menarik dari desa ini adalah warganya yang relejius, ini terbukti dengan jumlah Tuan Guru yang ada di desa Kekait cukup representatif dengan jumlah warganya, bahkan di desa Kekait terdapat pondok pesantren/madrasah yang telah berdiri sejak tahun 1975. Namun bila hal itu dijadikan tolak ukur kerelijiusan warganya maka dapat dikatakan bahwa keberadaan Tuan Guru dan madrasah belum berpengaruh signifikan terhadap sistem perkawinan warganya.

Dengan demikian, dapat dikatakan bahwa masyarakat atau warga desa Kekait masih dipengaruhi oleh adat istiadat dalam proses pra perkawinan. Bila demikian halnya, berarti pengaruh adat lebih dominan dibandingkan agama. Lalu apa saja faktor yang menyebabkan tradisi merariq masih tetap dilakukan oleh masyarakat Kekait. Hal tersebut perlu dicari jawabannya dengan melakukan penelitian di tengah

\footnotetext{
${ }^{5}$ Setelah mendata 100 kepala keluarga warga masyarakat kekait daye dari 422 kepala keluarga yang ada, maka didapatkan meraka yang melakukan pernikahan dengan sistem merariq sebanyak 90 kepala keluarga. Sedangkan yang melaksanakan pernikahan dengan sistem ngelakoq hanya 10 kepala keluarga. Data dapat dilihat dalam lampiran.

${ }^{6}$ Ibid,... hal. 245.
} 
masyarakat agar faktor - faktor yang melatar belakangi Tradisi Merariq itu dapat terungkap.

\section{B. Kajian Pustaka}

Menemukan berbagai faktor dilakukannya tradisi kawin lari dalam masyarakat Islam sasak di Lombok secara umum, berarti merekonstruksi dan mengulas kembali sejarah yang melatar belakangi munculnya tradisi tersebut.

Kepercayaan asli orang sasak adalah Boda sebelum datangnya pengaruh asing. Boda merupakan kepercayaan yang ditandai dengan animisme dan pantaisme. Setelah itu kerajaan Hindu-Majapahit dari Jawa Timur, masuk ke Lombok pada abad ke-7 dan memperkenlakan Hindu-Budhisme di kalangan orang sasak. Setelah jatuhnya dinasti Majapahit, agama Islam pertama kali disebarkan di Lombok oleh para raja muslim pada abad ke- 13. Pada abad ke 16 kerajaan makasar menguasai kerjaan Selaparang, dan mereka dianggap lebih berhasil mendakwahkan Islam suni. Selanjutnya pada abad ke- 17 kerajaan Bali Karangasem dapat menaklukkan kerajaan Lombok dan mengkonsolidasikan kekuasaanya setelah mengalahkan kerajaan Makasar. Namun, kerajaan Bali mendapat perlawan dari kalangan bangsawan Islam sasak dengan berbagi pemberontakan. Akhirnya kerajaan Bali meninggalkan Lombok setelah Belanda datang ${ }^{7}$.

Kawin lari (merariq) merupakan hasil akulturasi budaya dan bukan asli (ungenuine) dari leluhur masyarakat Sasak serta tidak dipraktikkan masyarakat sebelum datangnya kolonial Bali. Pendapat ini didukung oleh sebagian masyarakat Sasak dan dipelopori oleh tokoh agama, Pada tahun 1955 di Bengkel Lombok Barat,Tuan Guru Haji Saleh Hambali menghapus, kawin lari (merariq) karena dianggap manifestasi hinduisme Bali dan tidak sesuai dengan Islam. Hal yang sama

\footnotetext{
${ }^{7}$ Erni Budiwanti, Islam Sasak Wetu Telu.. , hlm. 9.
} 
dapat dijumpai di desa yang menjadi basis kegiatan Islam di Lombok, seperti Pancor, Kelayu, dan lain-lain. ${ }^{8}$

Tradisi merariq yang berlaku pada masyarakat sasak memiliki logika tersendiri. Bagi masyarkat Sasak, merariq berarti mempertahankan harga diri dan menggambarkan sikap kejantanan seorang pria Sasak, karena ia berhasil melarikan seorang gadis pujaan hatinya. Sementara pada sisi lain, bagi orang tua gadis yang dilarikan juga cenderung enggan, kalau tidak dikatakan gengsi, untuk memberikan anaknya begitu saja jika diminta secara biasa, karena mereka beranggapan bahwa anak gadisnya adalah sesuatu yang berharga, jika diminta secara biasa, maka dianggap seperti meminta barang yang tidak berharga. Bahkan ada ungkapan "perkawinan dengan cara meminta dianggap sama dengan meminta anak ayam”. Jadi, merariq dalam tradisi suku sasak adalah cara untuk melakukan prosesi pernikahan, di samping cara untuk keluar dari konflik.

\section{Pernikahan dalam Islam}

Pernikahan berasal dari bahasa Arab yaitu " nikah"نكاح dalam bahasa Indonesia diartikan dengan kata perkawinan. Nikah sendiri menurut bahasa semakna dengan kata " al-Dhammu atau al-Tadahkulu yang berarti berkumpul saling tindih dan saling memasukkan. ${ }^{9}$ Sedangkan menurut istilah, nikah diartikan sebagai suatu akad (perjanjian) yang mengandung kebolehan melakukan hubungan seksual dengan memakai lafaz "nikah" atau "tazawuj"10.

\section{Tujuan pernikahan Dalam Islam}

\footnotetext{
${ }^{8}$ Ahmad Abd Syakur, Akulturasi Nilai-nilai Islam dalam Budaya ..... hal. 248

${ }^{9}$ Muhammad ibn Ismail al-kahlani, Subulussalam, jilid 3, (Bandung: Maktabah Dakhlan), hal. 109

${ }^{10}$ Beni Ahmad Saebani, Fiqih Munakahat, (Bandung: Pustaka Setia, 2001), hlm. 11
} 
Pernikahan merupakan salah satu syareat agama-agama terdahulu sejak Nabi Adam sampai hari ini, bahkan akan tetap berlanjut sampai kehidupan di sorga. Menurut ahli kesehatan tujuan pernikahan itu ada tiga yaitu:

1. Menjaga keturunan

2. Mengeluarkan air (seperma) yang dapat membahayakan bila tetap mengendap di badan

3. Mencari kenikmatan ${ }^{11}$.

Sedangkan tujuan pernikahan yang sejati dalam Islam adalah pembinaan akhlak manusia sehingg hubungan yang terjadi antara gender yang berbeda dapat membangun kehidupan baru secara sosial dan kultural. Hubungan dalam bangunan tersebut adalah kehidupan rumah tangga dan terbentuknya generasi keturunan manusia yang memberikan kemaslahatan bagi masa depan masyarakat dan Negara.

\section{Khitbah/Melamar}

Islam memiliki tata cara tersendiri ketika seorang muslim ingin melangsungkan pernikahan. Sebelum pernikahan berlangsung calon mempelai lakilaki harus melakukan Khitbah atau lamaran terlebih dahulu kepada calon mempelai perempuan untuk diketahui persetujuannya menjadi istri dari calon mempelai lakilaki. Jadi khitbah adalah melamar seorang wanita untuk dipersunting dengan seorang peria. Khitbah adalah proses pendekatan yang dilakukan untuk mengetahui kelebihan dan kekurangan yang dimiliki seorang wanita sebelum dinikahi. Ada beberapa hal yang dilakukan ketika proses khitbah dilakukan yaitu, melihat wajah dan telapak tangan wanita calon mempelai, bahkan ada pendapat bahwa diperbolehkan untuk melihat seluruh tubuh. ${ }^{12}$ Hal tersebut dilakukan untuk menghindari cacat-cacat yang tersembunyi untuk menghindari adanya penyesalan setelah pernikahan dilakukan.

\footnotetext{
${ }^{11}$ Ibid,.. hal. 253

12 Muhammad ibn Ismail al-kahlani, Subulussalam... hal. 113.
} 


\section{Adat dan Tradisi}

Adat adalah bagian dari pada hukum yang telah disepakati oleh masyrakat tertentu yang dijadikan sebagai pedoman dalam segala tingkah laku ${ }^{13}$. Sehingga seseorang yang melanggar hukum adat akan mendapatkan sangsi dari masyarakat dimana adat tersebut diberlakukan. Dijadikannya adat sebagai sumber hukum dalam masyarakat karena adat memiliki manfaat seperti:

1. Adat sebagai pedoman hidup masyarakat dalam segala aktivitasnya ditengah masyarakat.

2. Adat dijadikan sebagai identitas yang dapat membedakan antara satu masyarakat dengan yang lainnya, jadi adat dapat Dikatakan sebagi jati diri suatu kelompok tertentu.

Menurut Rahmat Syafe`i dalam hukum Islam adat disebut `urf yang berarti keadaan, ucapan, perbuatan atau ketentuan yang telah dikenal manusia dan telah menjadi tradisi untuk dilaksanakan atau ditinggalkan. Karena adat atau 'urf dapat berubah sesuai dengan perkembangan zaman sehingga `urf tidak berlaku universal, bukan hanya lokal, bahkan `urf sifatnya parsial. `urf dapat berlaku di desa tertentu, tetapi bertentangan dengan desa lainnya. ${ }^{14}$ Dalam hukum Islam, adat dibagi menjadi dua, yaitu:

1. Adat shahihah, yaitu adat yang merupakan kebiasaan masyarakat yang tidak bertentangan dengan hukum yang lebih tinggi yang bersumber dari Al-Qur`an dan As-Sunah. Tidak bertentengan dengan akal sehat masyarakat.

2. Adat fasidah, yaitu adat yang rusak, sebagai adat kebiasaan yang bertentangan dengan Al-Qur`an dan As-Sunnah, bahkan bertentangan dengan akal sehat dan undang-undang yang berlaku. ${ }^{15}$

\footnotetext{
${ }^{13}$ Ahmad Junaedi, Adat Istiadat dan Pola Hidup....., hlm. 206

${ }^{14}$ Beni Ahmad Saebani, Sosiologi Hukum, (Bandung: Pustaka Setia, 2007), hal. 149-150.

${ }^{15}$ Ibid.. hal. 149.
} 


\section{Metodologi Penelitian}

Penelitian ini merupakan penelitian kualitatif yaitu sebuah prosedur penelitian yang menghasilkan data deskriptif berupa ucapan atau tulisan dan perilaku yang diamati dari orang-orang atau subyek itu sendiri. ${ }^{16}$ Dengan Pendekatan yang peneliti gunakan dalam penelitian ini, adalah pendekatan fenomenologi deskriptif, dimana penulis berusaha untuk memahami arti peristiwa dan kaitannya terhadap orang yang berada pada situasi tertentu.

Penelitan ini dilakukan di dusun Kekait Daye desa Kekait Kecamatan Gunung Sari Lombok Barat. Adapun yang menjadi sumber data dalam penelitian ini adalah: kepala desa Kekait, kepala dusun Kekait Daye, tokoh agama, tokoh masyarakat, tokoh pemuda serta dokumen-dokumen yang relevan dengan penelitian ini. Untuk memperoleh data yang jelas dalam penelitian ini, penulis menggunakan beberapa teknik yaitu observasi,Wawancara, dan dokumentasi. Setelah itu Validasi Data dengan teknik uji validitas data yang penulis lakukan adalah sebagai berikut:

1. Perpanjangan keikut sertaan

2. Pengecekan sejawat

3. Kecukupan Referensi ${ }^{17}$

\section{Hasil Temuan}

\section{Bentuk - Bentuk Perkawinan Pada Masyarakat Kekait}

Eksistensi sebuah adat budaya akan tetap terus bertahan ditengah masyarakat bila masyarakat secara terus menerus untuk mempertahankannya. Namun tidak dapat dipungkiri juga bahwa arus perubahan yang terus terjadi menyebabkan adat budaya di tengah masyarakat mengalami penurunan dan perubahan. Hal tersebut terjadi karena arus informasi dan modernisasi yang

\footnotetext{
${ }^{16}$ Arief Furchan, Pengantar Metode Penulisan Kualitatif, (Surabaya:Usaha Nasional, 1992), hal.21.

${ }^{17}$ Lexy J. Moleong. Metodologi, ....hal.327.
} 
sangat cepat melanda setiap sendi kehidupan masyarakat, sehingga mereka dengan sangat mudah untuk mengakses hal-hal di luar mereka untuk kemudian ditiru.

Begitu juga halnya dengan tradisi merariq yang ada pada masyarakat Kekait, yang mana terjadi degradasi nilai. Makna dan nilai tradisi merariq yang ada pada masyarakat Kekait terjadi penurunan bila dibandingkan dengan perkawinan yang dilakukan dengan sistem ngelakoq. Hal tersebut dikarenakan beberapa sebab; Pertama, pelaku sistem merariq umumnya dilakukan oleh mereka yang secara finansial belum memiliki kesiapan dibandingkan dengan pelaku sistem ngelakoq, dimana keberanian orang yang ngelakoq untuk melaksanakan perkawinan menandakan ia telah siap secara lahir batin. Kedua, perkawinan dengan sistem merariq umumnya dilakukan oleh masyarkat umum atau biasa. Sedangkan perkawinan dengan sistem ngelakoq adalah mereka yang memiliki pendidikan lebih tinggi, pekerjaan tidak sebagai petani (guru, PNS, pedagang) atau berasal dari keluarga yang mapan. Ketiga, orang yang ngelakoq disebut lebih berani dibandingkan mereka yang merariq, karena mereka dianggap tidak berani bertemu langsung dengan orang tua atau keluarga perempuan. Keempat, kesadaran untuk melaksanakan ajaran agama karena merariq dianggap kurang sopan, sedangkan ngelakoq itu ada tuntunannya dalam ajaran Islam. ${ }^{18}$

Meminang (ngelakoq) dianggap sebagai bagian dari pola hidup orang modern karena banyak dilakukan oleh mereka dengan status sosial yang lebih tinggi. Model perkawinan para artis atau anak para pejabat yang banyak disiarkan di televisi, setidaknya banyak mempengaruhi pola fikir masyarakat. Hal ini akan berdampak pada masyarakat Lombok yang memiliki tradisi merariq sebagai adat dan budaya. Pada akhirnya tradisi merariq akan mulai ditinggalkan karena alasan di atas atau karena sesungguhnya masyarakat di desa kekait

\footnotetext{
${ }^{18}$ Wawancara dengan Ust.Hafizin, S.Pd tokoh masyarakat Kekait pada hari senin 10 September 2012.
} 
meyakini bahwa ngelakoq merupakan bagian dari sistem beragama yang memiliki dasar dalam Islam. Secara tidak langsung tradisi merariq dan ngelakoq menjadi alat untuk membedakan setatus sosial seseorang ditengah masyarakat.

Selain itu ada nuansa yang sangat berbeda antara sistem merariq dengan sistem ngelakoq. Pada sisitem merariq, kesan perkawinan yang dilakukan terlihat biasa-biasa saja, dan sepertinya kesan kesakralan dari pernikahan itu tidak ada. Ini cukup beralasan karena banyak diantara mereka yang merariq belum memiliki kematangan mental sehingga perkawinan mereka harus terpisah dengan sebuah perceraian. ${ }^{19}$

Pada dasarnya merariq memiliki nilai filosofis yaitu: merariq sebagai tanda keberanian dan kesejatian kemudian merariq sebagai alternatif. ${ }^{20}$ Namun fenomena merariq yang terjadi di desa kekait cendrung pada merariq sebagai alternatif. Kenapa demikian! Karena bila seseorang ingin menikah kemudian belum memiliki pekerjaan, belum ada persiapan materi atau belum selesai kuliah maka mereka tidak akan pernah diizinkan untuk menikah. Namun bila merariq telah terjadi maka orang tua mau tidak mau harus tetap untuk melaksanakan pernikahan itu. ${ }^{21}$ selain itu, merariq juga merupakan alternatif bagi mereka yang nikah dini atau bagi mereka yang tidak direstui.

Dengan demikian, merariq bukan lagi sebagai simbol keberanian seperti nilai asal, namun sebaliknya merariq merupakan ketidak beranian seorang laki-laki untuk meminta izin secara langsung kepada orang tua perempuan untuk menikah. Di desa Kekait, seseorang yang ingin menikah dengan cara

\footnotetext{
${ }^{19}$ Taisir umur 15 tahun, dua bulan menukah sudah cerai, oci 20 tahun menikah hampri satu tahun sudah dua kali cerai.

${ }^{20}$ Avazuva, Pernikahan Adat Sasak, www.Pernikahan adat Sasak.htm., diakses pada 10 september 2012. ${ }^{21}$ Wawan cara dengan zaeful fahmi, helimi, saeful, safwan. Mereka adalah pelaku system merariq
wawan cara dilakukan pada tanggal 11, 12 dan 13 September 2012 .
} 
ngelakoq dianggap lebih beretika dan pemberani dibanding dengan seorang yang merariq. ${ }^{22}$

Melihat fenomena merariq dengan berbagai alasan dan penyebab terjadinya, lambat laun bahkan pada akhirnya merariq sebagai adat dan tradisi Sasak mulai tidak relefan lagi untuk dilaksanakan ditengah masyarakat. Selain faktor yang telah disebutkan sebelumnya, faktor semakin meningkatnya pemahaman agama pada masyarakat Kekait menjadi alasan untuk lebih mendorong masyarkatnya agar lebih mempersiapkan diri dalam melaksakan pernikahan, dan ngelakoq (khitbah) adalah alternatif untuk itu semua.

\section{Dampak Tradisi Merariq Dalam Kehidupan Masyarakat}

Segala sesuatu memiliki dua sisi, yaitu positif dan negatif. Demikian pula halnya dengan tradisi merariq yang terjadi di desa Kekait. Sisi positif yang terkandung dalam tradisi merariq adalah sifatnya yang praktis dan solutif. Merariq dianggap lebih praktis dibanding dengan ngelakoq karena merariq dapat dilakukan oleh siapapun tanpa harus terikat dengan syarat-syarat yang ketat berupa kesiapan mental (pendidikan yang memadai, pengetahuan tentang agama, dan kehidupan berumah tangga) serta material ( pekerjaan tetap yang akan menjadi penopang kehidupan rumah tangga, sekill untuk memperoleh pekerjaan).

Merariq juga dikatakan sebagai solusi, maksudnya bila seseorang yang memiliki hubungan (pacaran) antara laki-laki dengan seorang gadis, namun hubungan tersebut tidak direstui oleh orang tua diantra mereka karena berbagai alasan. Pada situasi seperti ini dua orang tadi biasanya bila saling menyayangi akan tetap berhubungan dengan cara rahasia. Ketika hubungan mereka tetap saja tidak direstui dan mereka ingin menikah, maka mereka akan melakukan merariq (kawin lari). Secara adat dan tradisi di Lombok seseorang yang telah dilarikan tidak dapat diambil kembali oleh orang tua si gadis. Bahkan akan menjadi suatu aib bagi kelurga si gadis bila itu terjadi atau akan terjadi perlawan oleh keluarga

\footnotetext{
${ }^{22}$ Wawancara dengan kepala desa H. syabri isyar,SH. Kamis 13 September 2012
} 
atau masyarakat. Dengan demikian pernikahan antara keduanya harus tetap dilaksanakan. Dengan demikian merariq adalah alternatif efektif dalam situasi seperti ini. ${ }^{23}$ Merariq dalam situasi seperti ini terkadang akan menjadi media yang efektif untuk menyambung tali silatirrahmi yang tadinya terputus. Orang tua yang awalnya tidak merestui, tetap saja harus menerima, karena mereka sudah menjadi bagian dari kelurga dalam bentuk mertua dan menantu.

Sedangkan sisi negatif dari tradisi merariq adalah perkawinan dini atau perkawinan di bawah umur. Seperti telah diketahui bersama bahwa perkawinan yang dilakukan oleh pasangan dibawah umur akan berdampak pada kesehatan, terutama bagi perempuan yang hamil dalam usia sangat muda.

Pemerintah sebenarnya telah mengatatur batas umur bagi laki-laki dan perempuan yang ingin menikah, yaitu 18 tahun untuk perempuan dan 20 untuk laki-laki. Sedangkan dalam tradisi merariq, siapapun yang melarikan seorang gadis untuk dinikahai dan mereka suka sama suka, maka tidak ada larangan bagi mereka walaupun dibawah umur sesuai dengan ketentuan diatas.

Dalam banyak aspek (ranah) kehidupan ternyata perempuan Sasak masih sangat marginal (inferior), sementara kaum laki-lakinya sangat superior. Marginalisasi perempuan dan superioritas laki-laki memang merupakan persoalan lama dan termasuk bagian dari peninggalan sejarah masa lalu. Sejak lahir perempuan Sasak mulai disubordinatkan sebagai orang yang disiapkan menjadi isteri calon suaminya kelak dengan anggapan " ja'ne lalo/ja'ne tebait si' semamenne" (suatu saat akan meninggalkan orang tua diambil dan dimiliki suaminya). Sementara, kelahiran seorang anak laki-laki pertama biasanya lebih disukai dan dikenal dengan istilah "anak prangge" (anak pewaris tahta orang tuanya).

Begitu juga tradisi perkawinan Sasak, seakan-akan memposisikan perempuan sebagai barang dagangan. Hal ini terlihat dari awal proses

${ }^{23}$ Wawancara dilakukan pada hari sabtu, 1 September 2012 di rumah H. Habibul mustaan. Beliau adalah penghulu desa Kekait. 
perkawinan, yaitu dengan dilarikannya seorang perempuan yang dilanjutkan dengan adanya tawar menawar uang pisuke (jaminan).

Terdapat beberapa dampak dari tradisi perkawinan adat Sasak (merariq) sebagai berikut: ${ }^{24}$

a. Suami memiliki sikap suprioritas dan otoriter atas istri dan anak-anak dalam menentukan keputusan keluarga. Hal terebut terjadi karena masih menguatnya patriarkhisme di tengah masyarakat ${ }^{25}$. Suami memiliki kekuasaan yang sangat besar atas istri, sehingga sang istri diumpamakan sebagai hamba sahaya milik suami. Berbagai pandangan yang menempatkan istri sebagai makhluk tak berdaya memiliki landasan normatif agama (hadis Nabi) ${ }^{26}$.

b. Istri hanya ditekankan untuk melaksanakan tugas-tugas domistik, sedangkan suami dianggap tabu jika lelaki (suami) Sasak mengerjakan tugas-tugas domestik. Suami akan dianggap lemah dan tidak memiliki karismatik bila melakukan pekerjaan-pekerjaan rumah tangga dalam masyarakat terdapat sebuah pernyataan bagi suami yang mengerjakan pekerjaan domistik yaitu, (ye kalah sik seninin).

c. Perempuan karier juga tetap diharuskan dapat mengerjakan tugas domestik di samping tugas atau pekerjaannya di luar rumah dalam memenuhi ekonomi keluarga (peran ganda).

d. Terjadinya praktek kawin-cerai yang sangat akut dan dalam kuantitas yang cukup besar di Lombok.

e. Terjadinya peluang berpoligami yang lebih besar bagi laki-laki (suami) Sasak dibandingkan lelaki (suami) dari etnis lain.

\footnotetext{
${ }^{24} \mathrm{Htp} / /$ www.pdslombokbaratkbp.tradisi-merarik-akulturasi-budaya-isla-htm. Diunduh pada tanggal 1 Sepember 2012 pada jam 17.00 WITA.

${ }^{25}$ Siti Ruhini Dzuhayatin, Pergulatan Pemikiran Feminis dalam Wacana Islam di Indonesia, (Yogyakarta: Pustaka Pelajar, 2002), hal. 9.

${ }^{26}$ Inayah Rahmaniyah, Penghambaan Istri Pada Suami, (Yogyakarta: eLSAQ Press, 2005) hal. 97.
} 
f. Nilai perkawinan menjadi ternodai jika dikaitkan dengan pelunasan uang pisuke.

g. Kalau terjadi perceraian, maka isterilah yang biasanya menyingkir dari rumah tanpa menikmati nafkah selama 'iddah. Istri yang dicerai tidak memperoleh harta gonogini walaupun harta tersebut diperoleh secara bersama.

\section{Peran madrasah}

Madrasah memiliki peran yang sangat penting dalam hal perkawinan ini, karena pembelajaran di madrasah setempat mengajarkan beberapa pengetahuan tentang pernikahan dan hal yang terkait di dalamnya. Dengan demikian, warga yang ada di masyarakat kekait tergolong masyarakat yang sadar hukum, baik hukum agama maupun hukum pemerintahan. Bagi yang tidak sekolah atau tidak pernah mengenyam pendidikan di madrasah bisa bertanya di ustaz atau guru-guru agama di madrasah. Diantara fungsi pendidikan madrasah adalah masyarakat secara berangsur-angsur kembali kepada petunjuk al-Qur'an dan sunnah seperti Ngelakoq atau khitbah dua diantara tradisi yang praktekkan di desa Kekait selain merariq. Ngelakoq memiliki nilai yang lebih tinggi dibandingkan merariq, karena bersumber dari agama dan berpegang pada nilai moral. Seseorang yang melaksanakan pernikahan dengan cara ngelakoq dipandang sebagai golongan kelas sosial tinggi, karena secara materi mereka adalah orang telah mapan, memiliki pekerjaan tetap dan sebagainya.

\section{E. SIMPULAN}

Dari seluruh ulasan yang telah dipaparkan dalam bab-bab sebelumnya, maka dapat disimpulkan sebagai berikut:

Kawin lari (merariq) merupakan hasil akulturasi budaya dan bukan asli (ungenuine) dari leluhur masyarakat Sasak serta tidak dipraktikkan oleh masyarakat sebelum datangnya kolonial Bali. Dalam adat Sasak pernikahan sering disebut dengan merariq yang berasal dari kata "lari" yang berarti melarikan 
atau kawin lari. Istilah merariq dalam adat sasak memiliki dua arti. Pertama, merariq adalah istlah khusus dalam sistem perkawinan dengan cara melarikan seorang gadis. Kedua, merariq berarti keseluruhan sistem dalam pelaksanaan perkawinan baik dengan cara melarikan gadis atau meminang. Merariq memiliki nilai filosofis, yaitu: keberanian dan alternatif. Terdapat beberapa proses kronologis dalam tradisi merariq yang harus dilalui seperti: midang, merariq, tesebok, nyelabar, besejati, pengendengan, kramen gubuk, begawe, bait wali, akad nikah, nyongkolan, dan nulakin lampak nae.

Tradisi merariq mengalami distorsi nilai karena banyak dilakukan oleh masyarakat dengan kelas sosial rendah. Selain itu makna filosofis yang terkandung dalam tradisi merariq bukan lagi sebagai bentuk keberanian namun sebaliknya. Merariq dijadikan sebagai alternatif praktis bagi mereka yang ingin menikah tetapi tidak mendapat restu dari orang tua.

Ngelakoq atau khitbah dua diantara tradisi yang praktekkan di desa Kekait selain merariq. Ngelakoq memiliki nilai yang lebih tinggi dibandingkan merariq, karena bersumber dari agama dan berpegang pada nilai moral. Seseorang yang melaksanakan pernikahan dengan cara ngelakoq dipandang sebagai golongan kelas sosial tinggi, karena secara materi mereka adalah orang telah mapan, memiliki pekerjaan tetap dan sebagainya.

\section{DAFTAR PUSTAKA}

Abdullah, Amin, Studi Agama Normativitas atau Historisitas, Yogyakarta: Pustaka Pelajar. 1999.

Abi Bakar, Sayid, Ianatut tahlibin, jilid 3, Surabaya: al-Hidayah.

Al-kahlani, Muhammad ibn Ismail, Subulussalam, jilid 3, Bandung: Maktabah Dakhlan.

Budiwanti, Erni, Islam Sasak Wetu Telu Versus Waktu Lima, Yogyakarta: LKis, 2000. 
Furchan, Arief , Pengantar Metode Penulisan Kualitatif, Surabaya:Usaha Nasional, 1992.

Hamim Ilyas, DKK, Perempuan Tertindas Kajian Hadis-Hadis “Misoganis”, Yogyakarta, eLSAQ Press 2005.

Siti Ruhaini, DKK, Rekonstruksi Metodologis Wacana Kesetaraan Jender dalam Islam, Yogyakarta: Pustaka Pelajar, 2002

Syakur, Ahmad Abd, Akulturasi Nilai-nilai Islam dalam Budaya Sasak, Yogyakarta: Adab Press, 2006.

Saebani, Beni Ahmad, Fiqih Munakahat, Bandung: Pustaka Setia, 2001.

Sugiono, Metode Penelitian Pendidikan Pendekatan Kuantitatif Kualitatif dan R\&D, Bandung:Alvabeta, 2009.

Muhammad Abu zahrah, Ushul Fiqih, Jakarta: Pustaka Firdaus, 2007.

Imam sudiayat, Hukum Adat Sketsa Asas, Yogyakarta: Liberty, 2007

Jurnal Transfomasi Fakultas Ilmu social Politik Universitas Muhammadiyah, 2011. 